\title{
Differential transport of embryos and degenerating ova by the oviducts of the long-tongued bat, Glossophaga soricina
}

\author{
J. J. Rasweiler IV* \\ Section of Genetics, Development and Physiology, Division of Biological Sciences, \\ Cornell University, Ithaca, New York 14853, U.S.A.
}

\begin{abstract}
Summary. Female long-tongued bats which had been maintained in sexually segregated groups in captivity for more than 8 months were bred and killed at various intervals between Days 1 and 25 post coitum. Their reproductive tracts were then examined histologically.

In 20 of the 28 bats carrying tubal embryos the remnants of 1-4 other ova were also observed in the oviductal ampullae. These remnants consisted of intact zonae pellucidae containing cellular debris, empty zonae, and/or zona fragments. Since long-tongued bats are monovular, the remnants had apparently been retained in the oviducts from previous, non-fertile reproductive cycles. In 27 of the 31 bats carrying implanting blastocysts, zonae pellucidae probably shed by the embryos had been retained in the oviducts. The remnants of 1-3 ova were also observed in the oviductal ampullae of 22 of the 31 bats carrying uterine blastocysts. In at least 14 of these bats the embryos had by-passed ovum remnants in the oviducts on their way to the uterus. No evidence of such remnants was found in the oviducts of 17 animals with tubal or uterine embryos, although old, as well as new, CL were present in the ovaries.
\end{abstract}

\section{Introduction}

Studies on a variety of mammals have established that unfertilized or degenerating ova are normally transported from the oviducts into the uterus (Austin \& Walton, 1960; Blandau, 1961). In mares and donkeys, however, such ova are usually retained in the oviducts, and only living embryos are transported into the uterus (Van Niekerk \& Gerneke, 1966; Steffenhagen, Pineda \& Ginther, 1972; Betteridge \& Mitchell, 1974, 1975; Onuma \& Ohnami, 1975; Betteridge, Flood \& Mitchell, 1976; Van Niekerk, 1976). It was briefly noted in a previous report (Rasweiler, 1972: p. 253) that the same phenomenon occurs in the common neotropical long-tongued bat, Glossophaga soricina. Ovum retention may also take place in another bat, Noctilio albiventris (Rasweiler, 1977). The present paper is a more thorough presentation of the observations which have been made on long-tongued bats.

In these bats both ovaries are functional although only one egg is normally ovulated. The tubal journey of the fertilized ovum is prolonged, requiring 11-13 days. The embryo develops to the blastocyst stage and sheds its zona pellucida in the oviduct. The blastocyst does not pass into the main cavity of the simplex uterus; rather, it lodges and implants in a narrow tubular region (the "intramural uterine cornu") interposed between what appears to be the actual end of the oviduct and the main uterine cavity. Therefore, during the early uterine stages of pregnancy it is readily apparent through which oviduct the embryo had passed (Rasweiler, 1972, 1974).

* Present address: Department of Anatomy, Cornell University Medical College, 1300 York Avenue, New York, New York 10021, U.S.A. 


\section{Materials and Methods}

All of the animals utilized in this study were captured in Trinidad, West Indies and maintained in a laboratory colony at Cornell University with methods which have been described elsewhere (Rasweiler, 1973). The female bats were housed in sexually segregated groups of 15-20/cage. Males were present in adjacent cages in the same small animal room. None of the females gave birth during the 8 month period between their capture and the first introduction of males for breeding purposes. From 1 to 3 males were then placed with each group of females. Vaginal smears were taken between 08:00 and 11:00 h each day and examined for the presence of spermatozoa. The day on which spermatozoa first appeared in a smear was considered to be Day 1 post coitum. The bats were killed between 10:00 and 13:00 h at various times between mating and Day 25 p.c.

\section{Histological procedures}

The entire reproductive tract from each animal was removed, opened at the level of the uterine isthmus and fixed in Helly's fluid for $6 \mathrm{~h}$ at room temperature or cold Carnoy's fluid $\left(4^{\circ} \mathrm{C}\right)$ for $8 \mathrm{~h}$. The tissues were then processed through organic solvents to paraffin wax, embedded, and serially sectioned at $5 \mu \mathrm{m}$. The Helly-fixed material was stained with haematoxylin and eosin, Masson's trichrome procedure, Azure A-eosin B at pH 4.5, and iron haematoxylin or an iron haematoxylin-periodic acid-Schiff (PAS) procedure. The Carnoy-fixed tissues were stained with the PAS procedure followed by a toluidine blue counterstain $(0.5 \%$ in $0.01 \mathrm{~N}-\mathrm{HCl}$ ) for $20 \mathrm{~min}$, with the Azure B method of Flax \& Himes (1952), or with Alcian blue $8 \mathrm{GX}(1 \%$ in $0.01 \mathrm{~N}-\mathrm{HCl})$ followed by a nuclear fast red counterstain. Some sections were exposed to $1 \%$ malt diastase for $30 \mathrm{~min}$ at room temperature, or soaked in distilled $\mathrm{H}_{2} \mathrm{O}$ for an equivalent period, before being stained by the $\mathrm{PAS}$-toluidine blue procedure. Other sections were exposed to beef pancreas RNAse $\left(10 \mathrm{mg} / 100 \mathrm{ml}\right.$ glass distilled $\mathrm{H}_{2} \mathrm{O}$ for $8 \mathrm{~h}$ at $37^{\circ} \mathrm{C}$ ), or to distilled water alone under equivalent conditions, before being stained by the Azure B method.

\section{Observations}

Of 29 bats examined between Day 1 and 13 p.c. 28 carried tubal embryos, and the other was not pregnant. In all of the pregnant animals the embryo was located in the ampulla of the oviduct ipsilateral to the ovary containing the newly ruptured follicle or the new corpus luteum (CL). None of these bats had other ruptured follicles or CL of the same age, but all possessed 1 or 2 older CL. In 20 of the 28 bats with tubal embryos remnants of other ova were also present in the oviducts (Table 1; Pl. 1, Figs 1-4). If the remnants consisted of an intact zona pellucida containing some cellular debris, it was classified as a 'degenerating ovum' (Pl. 1, Figs 2 and 3). In many cases the extra zonae observed in the oviduct were broken open and empty or fragmented (Pl. 1, Fig. 4). Only one of the tubal embryos, a blastocyst observed on Day 13 p.c. (see Rasweiler, 1974: Fig. 4), had shed its zona, and that lay free in the same oviduct. The number of degenerating ova and ova remnants found in the oviducts varied considerably (from 0 to 4 ) even between bats killed at about the same time after coitus. The dead ova and ova remnants in each animal usually, but not always, appeared to be in different stages of degeneration (Pl. 1, Figs 2, 3 , and 4). Typically such remnants were located in the ampulla, but fragments of zona pellucida were also occasionally seen in the isthmus.

Between Days 12 and 25 p.c., 38 bats were examined and 31 of these carried implanting blastocysts. All of the blastocysts were located on the side of the uterine fundus ipsilateral to the ovary containing the new CL. In 2 of the pregnant animals broken zonae were found in the intramural uterine cornu with the blastocysts, and in 2 others the zonae shed by the blastocysts 
Table 1. Incidence of ovum remnants* observed in the oviducts of 59 long-tongued bats carrying tubal embryos or uterine blastocysts

\begin{tabular}{|c|c|c|c|}
\hline \multirow[b]{2}{*}{$\begin{array}{l}\text { Oviductal contents on } \\
\text { non-pregnant side }\end{array}$} & \multicolumn{3}{|c|}{ Oviductal contents on pregnant side } \\
\hline & $\begin{array}{c}\text { No remnants of } \\
\text { other ova }\end{array}$ & $\begin{array}{c}\text { Remnants of } 1 \\
\text { other ovum }\end{array}$ & $\begin{array}{c}\text { Remnants of } 2 \\
\text { other ova }\end{array}$ \\
\hline No remnants of ova & $\left\{\begin{array}{l}\text { Tubal embryo, } 8 \text { bats } \\
\text { Uterine blastocyst, } \\
9 \text { bats }\end{array}\right.$ & $\begin{array}{l}\text { Tubal embryo, } 6 \text { bats } \\
\text { Uterine blastocyst, } \\
6 \text { bats } \dagger\end{array}$ & $\begin{array}{l}\text { Tubal embryo, } 1 \text { bat } \\
\text { Uterine blastocyst, } \\
1 \text { bat } \dagger\end{array}$ \\
\hline Remnants of 1 ovum & $\left\{\begin{array}{c}\text { Tubal embryo, } 9 \text { bats } \\
\text { Uterine blastocyst, } \\
8 \text { bats }\end{array}\right.$ & $\begin{array}{l}\text { Tubal embryo, } 1 \text { bat } \\
\text { Uterine blastocyst, } \\
6 \text { bats } \dagger\end{array}$ & $\begin{array}{l}\text { Uterine blastocyst, } \\
1 \text { bat } \dagger\end{array}$ \\
\hline Remnants of 2 ova & & & Tubal embryo, 1 bat \\
\hline Remnants of 3 ova & Tubal embryo, 1 bat & Tubal embryo, 1 bat & \\
\hline
\end{tabular}

- Excluding zonae pellucidae apparently shed by the embryos.

$\dagger$ In these bats the embryos had by-passed ovum remnants in the same oviduct.

could not be accounted for. Empty or fragmented zonae pellucidae were present in the ipsilateral oviduct in each of the remaining 27 pregnant bats, but it is uncertain precisely how many had been shed by the blastocysts and how many had surrounded other ova retained from previous, non-fertile cycles. For example, in a bat killed on Day 12 p.c. the blastocyst and a broken zona were lodged in the left intramural uterine cornu, while a degenerating ovum and another zona were present in the left ampulla. The empty zona in the oviduct had a more ragged appearance suggesting that it was probably older and not that which had surrounded the blastocyst. The appearance of the 2 empty zonae cannot be attributed to differences in processing since both were mounted on the same slide. Another empty, but reasonably intact, zona pellucida was observed in the uterus of a pregnant bat killed on Day 16 p.c. Since the remaining 12 animals with uterine blastocysts killed on Days 13-16 p.c. had only oviductal zonae, it seems likely that the zonae shed by the blastocysts had been retained by the oviducts (Pl. 1, Fig. 5).

Remnants of retained ova were observed in one or both oviducts in 22 of the 31 bats carrying uterine blastocysts (Table 1) and again there was considerable variation in the number found in different animals ( 0 to 3 /bat; Pl. 1, Figs 5-7). In at least 7 bats the embryos had actually bypassed degenerating ova (i.e. intact zonae often containing cellular debris) within the same oviduct on their way to the uterus (Pl. 1, Figs 5 and 6). In 7 other bats carrying uterine blastocysts an excess of empty zonae was evident in the ipsilateral oviduct, indicating that the embryos had also by-passed ova remnants in the oviducts of those animals.

Discrepancies were noted in many of the bats between the number of embryos plus ova remnants which were found and the count of ruptured follicles plus CL. In 17 pregnant animals there was no evidence of retained ova, although old CL were present in addition to recently ruptured follicles or new CL. Fewer embryos or ova remnants than ruptured follicles and CL were counted in 13 other animals (9 pregnant and 4 non-pregnant), while the number of embryos plus ova remnants exceeded the count of ruptured follicles plus CL in 10 pregnant and 1 of the non-pregnant bats.

\section{Discussion}

All of the long-tongued bats examined in the present study were monovular, and most carried tubal or early uterine embryos. In addition the remnants of extra ova, presumably released during previous non-fertile cycles, were frequently noted in their oviducts. Although it is just possible that some of the degenerating ova may have originated from the same follicles as the 
ova which were fertilized, several lines of evidence weigh heavily against this explanation for the presence of most of the ova remnants. Polyovular follicles were seen only very rarely in the ovaries, and none of the large, apparently healthy vesicular follicles observed in a total of 10 bats killed late in non-pregnant reproductive cycles were polyovular (J. J. Rasweiler, unpublished observations). Furthermore, the ova within each animal usually (but not always) seemed to be in different stages of degeneration, suggesting that they had been ovulated at different times. Finally in many of the bats carrying implanting blastocysts, degenerating ova and/or zonae were observed in the ipsilateral oviduct through which the embryo had passed, indicating that the oviducts in this species can somehow distinguish between healthy embryos and dead ova or empty zonae. This also establishes that the oviducts were functionally normal (i.e. capable of maintaining and then transporting embryos into the uterus).

In many of the long-tongued bats examined, the number of embryos and ova remnants found did not equal the count of ruptured follicles and CL. Some old CL had probably involuted completely. These discrepancies may also be partly attributable to the difficulties of identifying $\mathrm{CL}$ in an advanced state of regression and of locating shrunken or fragmented zonae. There were, however, frequently marked differences between animals killed at approximately the same time post coitum in the number of degenerating ova counted. This suggests that such ova may be eliminated more rapidly from the oviducts of some individuals and that newly ovulated ova may not always be transported into the oviducts. The ovarian bursa of the long-tongued bat is incomplete (see Rasweiler, 1972, Fig. 1). Considerable variation has also been reported in the number of degenerating ova recovered from mares, and frequently none was found (Steffenhagen et al., 1972; David, 1975). Such counts varied significantly between two breeds of horses examined by Onuma \& Ohnami (1975).

\section{EXPLANATION OF PLATE 1}

Fig. 1. Day 5 p.c. showing a 4-cell embryo in the ampulla of the right oviduct. The remnants of 3 degenerating ova were also found in the oviducts of this bat (see Figs 2-4). PAS-toluidine blue. $\times 305$.

Fig. 2. Day 5 p.c. Sections through the centre of one degenerating ovum and the zona pellucida of a second (arrow) in the ampulla of the left oviduct. Cytoplasmic debris is present inside the intact zona on the left. PAS-toluidine blue. $\times 305$.

Fig. 3. Day 5 p.c. Section through the centre of the second degenerating ovum (arrowed in Fig. 2) in the ampulla of the left oviduct. There is also some debris inside this intact zona. PAStoluidine blue. $\times 305$.

Fig. 4. Day 5 p.c. Fragments of a zona pellucida (arrows) retained in the ampulla of the left oviduct. Since the zonae shown in Figs 2 and 3 were intact, these fragments must be the remnants of a third degenerating ovum. PAS-toluidine blue. $\times 305$.

Fig. 5. Day 18 p.c. Degenerating ovum and a broken zona pellucida in the ampulla of the left oviduct. The empty zona had probably been shed by a blastocyst which was implanting in the left intramural uterine cornu. Two other degenerating ova (Figs 6 and 7) were found in the oviducts of this bat. PAS-toluidine blue. $\times 305$.

Fig. 6. Day 18 p.c. Another empty, but reasonably intact, zona pellucida found in the ampulla of the left oviduct with the degenerating ovum and the broken zona shown in Fig. 5. Only one CL (i.e. the CL of pregnancy) was found in the left ovary. Alcian blue-nuclear fast red. $\times 305$.

Fig. 7. Day 18 p.c. Degenerating ovum in the ampulla of the right oviduct. An old CL was present in the right ovary. PAS-toluidine blue. $\times 305$. 

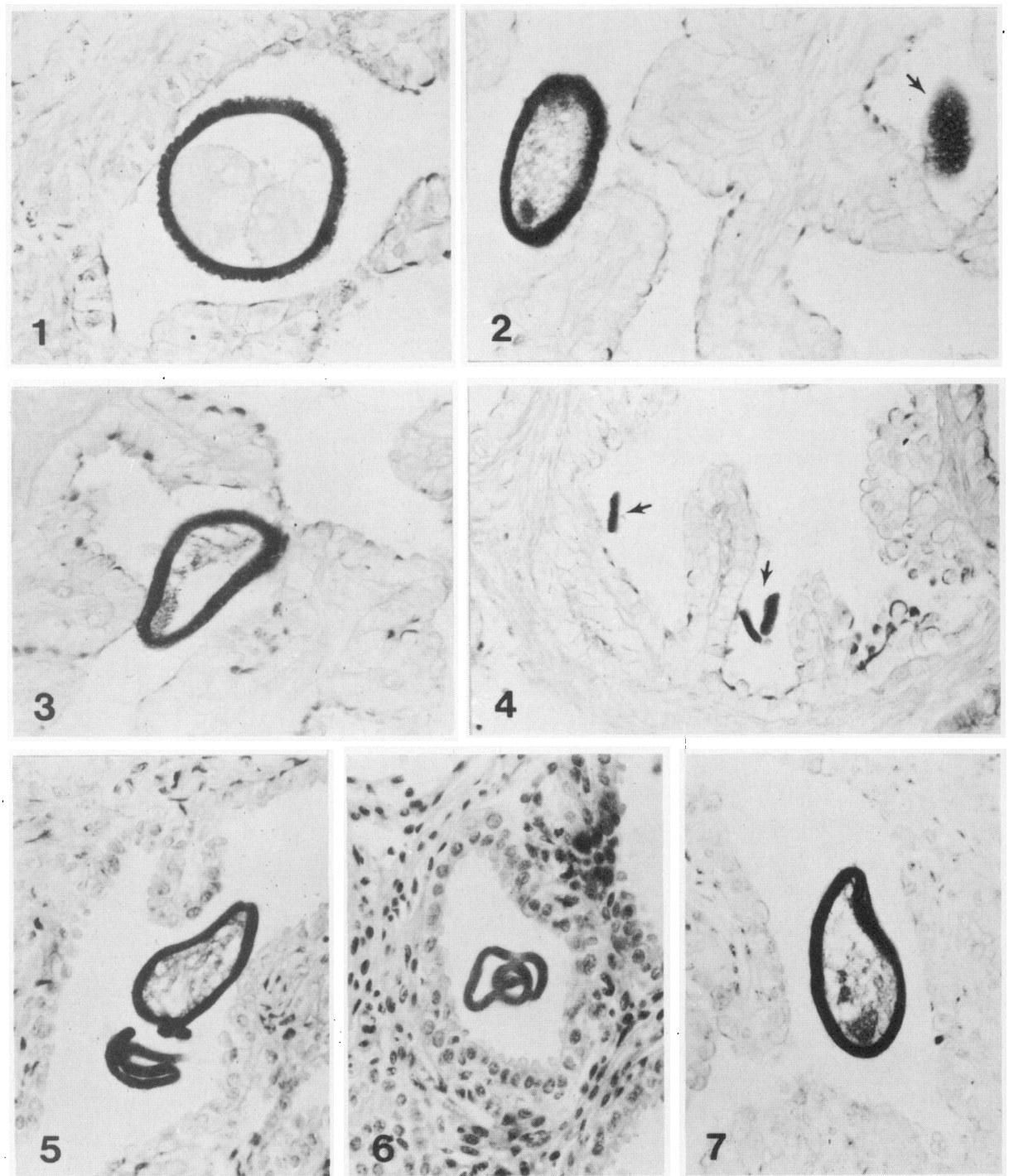
Only 2 cases of oviductal retention of degenerating ova were observed in the little bulldog bat, Noctilio albiventris (Rasweiler, 1977). Since both were contralateral to implanting blastocysts, the possibility could not be excluded that malfunctioning of the maternal reproductive tract, e.g. at the ovarian or oviductal level on the non-pregnant side, might have been responsible for ovum retention. There is increasing evidence, however, that $N$. albiventris and $G$. soricina are relatively closely related bats, and a similar ovum transport mechanism might therefore exist in both species.

Although degenerating ova from previous ovulations have been noted in the oviducts of some unmated senescent mice and hamsters, and more rarely in the oviducts of young hamsters, dead eggs are normally transported into the uterus in mature, non-senescent females of both species (Parkening, 1976). It was suggested that the retention phenomenon in aged mice and hamsters might be the result of hormonal imbalances or deficiencies.

The mechanism(s) which might be responsible for the differential transport of fertilized and unfertilized ova (or degenerating embryos) in $G$. soricina, some equids and possibly $N$. albiventris remain(s) to be identified. Since horse embryos are still encased by a zona pellucida when they pass into the uterus (Oguri \& Tsutsumi, 1972) fertilization may bring about changes in the zona which later permit only zona-encased embryos to be transported out of the oviducts. Although no marked surface differences have been observed between the zonae of fertilized and unfertilized ova (Betteridge et al., 1976), the solubility properties of zonae pellucidae surrounding fertilized and unfertilized mouse ova have been found to differ (Inoue \& Wolf, 1974). The differential transport of living and dead ova in long-tongued bats cannot be attributed to changes in the zona brought about by fertilization because a substantial number of blastocysts shed their zonae before escaping from the oviducts (Rasweiler, 1972). This suggests that the transport process in these bats may rely upon the presence or absence of a zona pellucida to distinguish between living and dead ova; however, there is no evidence that zona shedding is an absolute prerequisite for ovum transport in $G$. soricina, and zonae were in fact observed next to early implanting blastocysts in the uteri of 2 animals.

Perhaps the ovum transport mechanism of this bat (1) distinguishes between living and dead ova on the basis of other physical differences, e.g. in size, shape or resiliency, or (2) responds to a metabolite or humoral agent released by the embryo. Some evidence for a local effect of cumulus masses or embryos upon motility of the oviduct or uterus has been obtained from work with other mammals (see Blandau, 1969, p. 136; Cloud \& Casida, 1969; Humphrey, 1970; Böving, 1971). Since living embryos can by-pass degenerating ova in the same oviduct, the selectivity of the transport process in the long-tongued bat cannot be attributed to a change in ovarian steroid secretion in response to a gonadotrophin produced by the embryo. The possibility remains that steroids synthesized by the embryo might trigger the ovum transport mechanism. The preimplantation embryos of several mammals contain steroidogenic enzymes and blastocysts of the rabbit and pig have been found to be capable of synthesizing some steroids (Dickmann, Dey \& Sen Gupta, 1976; Niimura \& Ishida, 1976). Recent studies have failed to provide evidence, however, that preimplantation mouse and rabbit embryos synthesize oestrogens or progesterone (Sherman \& Atienza, 1977; Antila, Koskinen, Niemelä \& Saure, 1977; Borland, Erickson \& Ducibella, 1977; Fujimoto \& Sundaram, 1978). If ovum transport in the long-tongued bat is triggered by a metabolite or hormone diffusing away from the embryo, it remains unclear how the effect could be localized (particularly at the level of the tunica muscularis within the oviductal wall) so as to permit the retention of dead ova and empty zonae by the same oviduct. Although a central role for the tunica muscularis cannot be discounted at this time, consideration should also be given to the possibility that transport through the isthmus in this species may depend upon the local stimulation of ciliary activity around the ambryo. However, relatively few ciliated cells are

This research was supported in part by NIH Training Grant HD 00171-04 and by NSF Research Grant GB-6435X to Dr William A. Wimsatt. The generous assistance of Mr Anthony Guerriere, Dr Kathryn Martin and Dr William A. Wimsatt is gratefully acknowledged. 
present in the last portion of the oviduct (the junctura) and they are absent from the intramural uterine cornu in long-tongued bats. It therefore seems doubtful that ciliary activity alone could be responsible for transport of the blastocyst to the site of implantation.

\section{References}

Antila, E., Koskinen, J., Niemelä, P. \& Saure, A. (1977) Steroid metabolism by mouse preimplantation embryos in vitro. Experientia 33, 1374-1375.

Austin, C.R. \& Walton, A (1960) Fertilisation. In Marshall's Physiology of Reproduction, Vol. I, Part Two, pp. 310-416. Ed. A. S. Parkes. Longmans, Green \& Co. Ltd, London.

Betteridge, K.J. \& Mitchell, D. (1974) Direct evidence of retention of unfertilized ova in the oviduct of the mare. J. Reprod. Fert. 39, 145-148.

Betteridge, K.J. \& Mitchell, D. (1975) Surgical technique applied to the study of tubal eggs in the mare. $J$. Reprod. Fert., Suppl. 23, 519-524.

Betteridge, K.J., Flood, P.F. \& Mitchell, D. (1976) Possible rôle of the embryo in the control of oviductal transport in mares. In Ovum Transport and Fertility Regulation, pp. 381-389. Eds M. J. K. Harper, C. J. Pauerstein, C. E. Adams, E. M. Coutinho, H. B. Croxatto \& D. M. Paton. Scriptor, Copenhagen.

Blandau, R.J. (1961) Biology of eggs and implantation. In Sex and Internal Secretions, Vol. II, 3rd edn, pp. 797-882. Eds W. C. Young and G. W. Corner. Williams \& Wilkins, Baltimore.

Blandau, RJ. (1969) Gamete transport-comparative aspects. In The Mammalian Oviduct, pp. 129-162. Eds E. S. E. Hafez \& R. J. Blandau. University of Chicago Press, Chicago.

Borland, R.M., Erickson, G.F. \& Ducibella, T. (1977) Accumulation of steroids in rabbit preimplantation blastocysts. J. Reprod. Fert. 49, 219-224.

Böving, B.G. (1971) Biomechanics of implantation. In Biology of the Blastocyst, pp. 423-442. Ed. R. J. Blandau. University of Chicago Press, Chicago.

Cloud, J.G. \& Casida, L.E. (1969) Local effect of the early sheep embryo upon uterine motility. J. Anim. Sci. 29, 48-50.

David, J.S.E. (1975) Survey of eggs in the oviducts of mares. J. Reprod. Fert., Suppl. 23, 513-517.

Dickmann, Z., Dey, S.K. \& Sen Gupta, J. (1976) A new concept: control of early pregnancy by steroid hormones originating in the preimplantation embryo. Vitams Horm. 34, 215-242,

Flax, M.H. \& Himes, M.H. (1952) Microspectrophotometric analysis of metachromatic staining of nucleic acids. Physiol. Zool. 25, 297-311.

Fujimoto, S. \& Sundaram, K. (1978) The source of progesterone in rabbit blastocysts. J. Reprod. Fert. 52, 231-233.
Humphrey, K.W. (1970) Mechanisms concerned in ovum transport. Adv. Biosci. 4, 133-148.

Inoue, M. \& Wolf, D.P. (1974) Comparative solubility properties of the zonae pellucidae of unfertilized and fertilized mouse ova. Biol. Reprod. 11, 558-565.

Niimura, S. \& Ishida, K. (1976) Histochemical studies of $\Delta^{5}-3 \beta-, 20 \alpha$ - and $20 \beta$-hydroxysteroid dehydrogenases and possible progestagen production in hamster eggs. $J$. Reprod. Fert. 48, 275-278.

Oguri, N. \& Tsutsumi, Y. (1972) Non-surgical recovery of equine eggs, and an attempt at non-surgical egg transfer in horses. J. Reprod. Fert. 31, 187-195.

Onuma, H. \& Ohnami, Y. (1975) Retention of tubal eggs in mares. J. Reprod. Fert., Suppl. 23, 507-511.

Parkening, T.A. (1976) Retention of ova in oviducts of senescent mice and hamsters. J. exp. Zool. 196, 307314.

Rasweiler, J.J., IV (1972) Reproduction in the longtongued bat, Glossophaga soricina. I. Preimplantation development and histology of the oviduct. $J$. Reprod. Fert. 31, 249-262.

Rasweiler, J.J., IV (1973) The care and management of the long-tongued bat, Glossophaga sorcina (Chiroptera: Phyllostomatidae) in the laboratory, with observations on estivation induced by food deprivation. J. Mammal. 54, 391-404.

Rasweiler, J.J., IV (1974) Reproduction in the longtongued bat, Glossophaga soricina. II. Implantation and early embryonic development. Am.J. Anat. 139, $1-36$.

Rasweiler, J.J., IV (1977) Preimplantation development, fate of the zona pellucida, and observations on the glycogen-rich oviduct of the little bulldog bat, Noctilio albiventris. Am. J. Anat. 150, 269-300.

Sherman, M.I. \& Atienza, S.B. (1977) Production and metabolism of progesterone and androstenedione by cultured mouse blastocysts. Biol. Reprod. 16, 190199.

Steffenhagen, W.P., Pineda, M.H. \& Ginther, O.J. (1972) Retention of unfertilized ova in uterine tubes of mares. Am. J. vet. Res 33, 2391-2398.

Van Niekerk, C.H. (1976) Retention of unfertilized ova in the oviducts of mares. In Ovum Transport and Fertility Regulation, pp. 375-380. Eds M. J. K. Harper, C. J. Pauerstein, C. E. Adams, E. M. Coutinho, H. B. Croxatto \& D. M. Paton. Scriptor, Copenhagen.

Van Niekerk, C.H. \& Gerneke, W.M. (1966) Persistence and parthenogenetic cleavage of tubal ova in the mare. Onderstepoort J. vet. Res. 31, 195-232. 